\title{
Growth Performance of Mature Trees Resulted from Intra and Inter-specific Grafting on Robusta Coffee
}

\author{
DOI: $10.18196 /$ pt.2018.083.77-83
}

\author{
Rusdi Evizal $^{1 *}$, Sugiatno ${ }^{2}$, Setyo Dwi Utomo ${ }^{2}$, Hidayat Pujisiswanto ${ }^{2}$, Setyo Widagdo ${ }^{1}$, \\ Fembriarti Erry Prasmatiwi ${ }^{3}$, Aresta Dwi Stiawan ${ }^{1}$ \\ ${ }^{1}$ Department of Agrotechnology, Faculty of Agriculture, University of Lampung \\ ${ }^{2}$ Department of Agronomy and Horticulture, Faculty of Agriculture, University of Lampung \\ ${ }^{3}$ Department of Agribusiness, Faculty of Agriculture, University of Lampung, \\ Jl. Sumantri Brojonegoro I, Gedong Meneng, Rajabasa, Kota Bandar Lampung, Lampung 35141, Indonesia, Telp: (0721) 704622 \\ *Corresponding author, email: rusdi.evizal@fp.unila.ac.id
}

\begin{abstract}
To improve yield and cup quality, mature coffee tree as rootstock could be grafted with scion of selected genotype. This research aimed to study growth performance of mature trees resulted from intra and inter-specific grafting on Robusta coffee. The research was arranged in Randomized Complete Block Design with 3 replications. There were 12 treatments of entrees/under-stump genotype for coffee grafting including 8 treatments of intraspesific local Robusta/Robusta grafting and 4 treatments of interspecific coffee grafting of Robusta/Liberica and Arabica/Robusta. The results showed that intraspecific grafting of Robusta/Robusta, Robusta/Liberica, and Arabica/Robusta resulted in grafting mortality of 9.8\%, 10.9\%, and 24.8\%, respectively. Until 28 weeks after grafting, branch growth variables were significantly affected by scion/rootstock of Robusta/Robusta, Robusta/Liberica, and Arabica/Robusta grafting. Grafted Arabica/Robusta coffee showed the poor growth performance. In second year of Robusta/Robusta and Robusta/Liberica growth, generative growth of cherry inflorescence per branch and number of cherries per inflorescence were not affected by scion and rootstock genotypes. Leaf and branch growth were very important variables correlating with other variables.
\end{abstract}

Keywords: Coffee, Grafting, Intraspecific, Interspecific, Robusta

\section{ABSTRAK}

Untuk meningkatkan produksi dan citarasa kopi, pohon dewasa sebagai batang bawah dapat disambung dengan entres batang atas dari genotype unggul terpilih. Penelitian ini bertujuan untuk mempelajari pertumbuhan kopi Robusta sambungan intra dan inter-spesifik pada pohon dewasa. Penelitian menggunakan rancangan kelompok teracak lengkap dengan 3 ulangan. Perlakuan terdiri dari 12 kombinasi batang atas/batang bawah yang terdiri dari 8 kombinasi perlakuan batang atas/batang bawah dari genotipe Robusta/Robusta, 2 kombinasi Robusta/Liberica, dan 2 kombinasi Arabica/Robusta. Hasil menunjukkan bahwa mortalitas penyambungan Robusta/Robusta adalah 9,8\%, Robusta/Liberica 10,9\%, dan Arabica/Robusta 24,8\%. Sampai 28 minggu setelah penyambungan, pertumbuhan daun dan cabang dipengaruhi oleh genotipe batang atas/batang bawah baik perlakuan Robusta/Robusta, Robusta/ Liberica, maupun Arabica/Robusta. Cabang sambungan Arabica/Robusta menunjukkan pertumbuhan yang paling lambat. Pertumbuhan generative tahun kedua Robusta/Robusta and Robusta/Liberika yaitu dompol buah per cabang dan jumlah buah per dompol tidak dipengaruhi oleh genotype batang atas/ batang bawah. Pertumbuhan daun dan cabang merupakan variable penting yang berkorelasi dengan banyak variable lainnya.

Kata Kunci: Kopi, Penyambungan, Intraspesifik, Interspesifik, Robusta

\section{INTRODUCTION}

Grafting and cutting are the means for veg- generally recommended for trees which are prone etative propagation in coffee plants. Grafting somehow results in more superior seedlings than to diseases with low productivity.

cutting (Junior et al., 2013). Grafting is also used

Warshefsky et al. (2016) stated that by grafting, for rehabilitating or rejuvenating coffee plantation to improve growth, yield, resistance to nematode, and cup quality. Wintgens and Zamarripa (2004) stated that rehabilitation was used for restoring or improving yield. This technique is now an important factor for higher productivity which is besides to manipulate scion phenotype, rootstocks provide benefit to improve and expand woody perennial cultivation in a range of environmental conditions. For sustainable Arabica coffee (Coffea arabica) production, Alnopri and Hermawan (2015) suggested that Arabica coffee plantation is shifted from high altitude areas to lowland areas by inter- 
Table 1. Entrees/under-stump treatments

\begin{tabular}{|c|c|c|c|}
\hline Grafting system & Coffee species & Entrees/under-stumplocal genotype & Treatment name \\
\hline \multirow[t]{8}{*}{ Intraspecific } & Robusta/Robusta & Tugu Sari/Bakir & $\mathrm{TS} / \mathrm{Ba}$ \\
\hline & & Tugu Hijau/Bakir & $\mathrm{TH} / \mathrm{Ba}$ \\
\hline & & Ciari/Bakir & $\mathrm{Ci} / \mathrm{Ba}$ \\
\hline & & Ersad/Bakir & $\mathrm{Er} / \mathrm{Ba}$ \\
\hline & & Tugu Sari/Garudak & $\mathrm{TS} / \mathrm{Ga}$ \\
\hline & & Tugu Hijau/Garudak & $\mathrm{TH} / \mathrm{Ga}$ \\
\hline & & Ciari/Garudak & $\mathrm{Ci} / \mathrm{Ga}$ \\
\hline & & Ersad/Garudak & $\mathrm{Er} / \mathrm{Ga}$ \\
\hline \multirow[t]{2}{*}{ Interspecific } & Robusta/Liberica & Tugu Sari/Robinson & TS/Ro \\
\hline & & TuguHijau/Robinson & TH/Ro \\
\hline \multirow[t]{2}{*}{ Interspecific } & Arabica/Robusta & Kartika/Bakir & $\mathrm{Ka} / \mathrm{Ba}$ \\
\hline & & Kartika/Garudak & $\mathrm{Ka} / \mathrm{Ga}$ \\
\hline
\end{tabular}

specific grafting using rootstock of Robusta coffee (Coffeacanephora var. Robusta) which is agro-climatically suitable to grow in lowland areas. To improve growth and production, Pranowo and Supriadi (2013) suggested selection of high yielding Robusta clone BP 430 for intra-specific grafting with local Robusta clones since the grafting of clone BP 430 showed better growth than other clones.

The growth performance of coffee grafting depends on rootstock and scion genotype. Compatible grafting of Arabica onto Robusta might result in better growth of plant height and leaf area than non-grafted Arabica (Tomaz et al., 2002). Grafting Arabica onto Robusta would improve net photosynthesis of Arabica coffee. Moreover, grafted plants would have lower susceptibility to water stress by increasing positive components of leaf carbon balance especially under high vapor pressure deficit condition (Novaes et al., 2011) due to the greater capacity of the root system of Robusta coffee to provide water to the shoot thereby maintaining greater gas exchange in the leaves and consequently a greater carbon gain (Fahl et al., 2001).

Grafting C. arabica cv Catuai plants onto C. canephora cv Apoatoa increases branches per plant, pairs of leaves per plant, canopy area, total leaf area of plant, average area of a leaf, internode length, plant height, canopy diameter and coffee yield but does not affect the cup quality (Fahl et al., 2001). According to Wintgens and Zamarripa (2004) advantages of grafting Arabica onto Canephora include: (1) it offers the possibility of establishing Arabica in soils which have a high root parasite rating (nematode, root-scales, etc.), (2) the maturation of the cherries will be more uniform because the plant will have a higher tolerance to water-deficient soil, (2) the lifespan of the coffee plantation will be longer because physical defects and unproductive coffee trees will only appear at a later date.

In Latin America, interspecific grafting of Arabica coffee onto Robusta coffee is commonly practiced in order to avoid nematode attack. Grafting of C. arabica cv Caturra plants onto C. canephora decreases plant height, branch length, fruit yield but does not decrease aroma, body, acidity and bitterness of cup quality (Bertrand and Etienne, 2001). Meanwhile, Excelsa coffee (Coffealiberica var. dewevrei) is commonly used as rootstock because it has strong root growth and resistance to nematode (Udarno and Setiyono, 2015). In West Lampung, the center of Indonesia Robusta coffee, interspecific grafting of Robusta coffee on Liberica coffee (Coffealiberica) is applied to change Liberica coffee plantation to Robusta coffee plantationand 
Table 2. Grafting Success Rate and Branch Growth at 28 Weeks after Grafting

\begin{tabular}{lcccccc}
\hline $\begin{array}{c}\text { Scion/rootstock } \\
\text { genotype }\end{array}$ & $\begin{array}{c}\text { Grafting Sprouting } \\
(\%)\end{array}$ & $\begin{array}{c}\text { Branch girth } \\
(\mathbf{c m})\end{array}$ & $\begin{array}{c}\text { Numbe of } \\
\text { leaves }\end{array}$ & $\begin{array}{c}\text { Primary branch length } \\
(\mathbf{c m})\end{array}$ & $\begin{array}{c}\text { Secondary branch length } \\
(\mathbf{c m})\end{array}$ & $\begin{array}{c}\text { Number of } \\
\text { branches }\end{array}$ \\
\hline Tugu Sari/Bakir & $97.2 \mathrm{a}$ & $0.27 \mathrm{a}$ & $33.0 \mathrm{a}$ & $22.54 \mathrm{a}$ & $4.52 \mathrm{a}$ & $2.58 \mathrm{a}$ \\
TuguHijau/Bakir & $92.3 \mathrm{a}$ & $0.40 \mathrm{a}$ & $15.1 \mathrm{a}$ & $14.45 \mathrm{a}$ & $1.77 \mathrm{a}$ & $2.14 \mathrm{a}$ \\
Ciari/Bakir & $73.3 \mathrm{a}$ & $0.20 \mathrm{a}$ & $19.4 \mathrm{a}$ & $13.08 \mathrm{a}$ & $0.19 \mathrm{a}$ & $2.41 \mathrm{a}$ \\
Ersad/Bakir & $93.3 \mathrm{a}$ & $0.19 \mathrm{a}$ & $21.9 \mathrm{a}$ & $17.06 \mathrm{a}$ & $0.39 \mathrm{a}$ & $2.16 \mathrm{a}$ \\
Tugu Sari/Garudak & $96.6 \mathrm{a}$ & $0.32 \mathrm{a}$ & $29.7 \mathrm{a}$ & $26.94 \mathrm{a}$ & $2.91 \mathrm{a}$ & $2.66 \mathrm{a}$ \\
TuguHijau/Garudak & $93.3 \mathrm{a}$ & $0.28 \mathrm{a}$ & $38.7 \mathrm{a}$ & $21.73 \mathrm{a}$ & $3.40 \mathrm{a}$ & $3.00 \mathrm{a}$ \\
Ciari/Garudak & $85.3 \mathrm{a}$ & $0.21 \mathrm{a}$ & $23.3 \mathrm{a}$ & $17.93 \mathrm{a}$ & $2.64 \mathrm{a}$ & $2.16 \mathrm{a}$ \\
Ersad/Garudak & $90.3 \mathrm{a}$ & $0.19 \mathrm{a}$ & $17.9 \mathrm{a}$ & $12.98 \mathrm{a}$ & $1.08 \mathrm{a}$ & $2.25 \mathrm{a}$ \\
Tugu Sari/Robinson & $88.3 \mathrm{a}$ & $0.22 \mathrm{a}$ & $17.3 \mathrm{a}$ & $15.58 \mathrm{a}$ & $2.39 \mathrm{a}$ & $2.41 \mathrm{a}$ \\
TuguHijau/Robinson & $90.0 \mathrm{a}$ & $0.26 \mathrm{a}$ & $24.1 \mathrm{a}$ & $18.14 \mathrm{a}$ & $2.56 \mathrm{a}$ & $2.66 \mathrm{a}$ \\
Kartika/Bakir & $80.3 \mathrm{a}$ & $0.16 \mathrm{a}$ & $16.3 \mathrm{a}$ & $9.27 \mathrm{a}$ & $2.08 \mathrm{a}$ & $1.91 \mathrm{a}$ \\
Kartika/Garudak & $70.2 \mathrm{a}$ & $0.17 \mathrm{a}$ & $22.0 \mathrm{a}$ & $9.26 \mathrm{a}$ & $0.16 \mathrm{a}$ & $1.83 \mathrm{a}$ \\
\hline
\end{tabular}

Note: Numbers followed by the same letter in the same column were not significantly different according to LSD at 5\%.

to mitigate drought season. Furthermore, intraspecific coffee grafting of local Robusta/Robusta is commonly practiced improving coffee growth and yield. Farmers commonly practice self-breeding to select better local genotypes to use as grafting materials (Evizal et al., 2015). According to Van der Vossen (2001) a marked hybrid vigor for yield in progenies could be achieved from inter-population crosses. This research aimed to study the growth performance of matere trees propagated from intra and inter-specific grafting of Robusta coffee.

\section{MATERIALS AND METHODS}

The research was conducted in 2016-2018 at experimental coffee plantation in Sumberjaya, West Lampung Province, Indonesia located at $05^{\circ} 02^{\prime} 64^{\prime \prime} \mathrm{S}$ and $104^{\circ} 24^{\prime} 37^{\prime \prime}$ E with elevation of $860 \mathrm{~m}$ above sea level. The research was arranged in Randomized Complete Block Design with 3 replications. There were 12 treatments of scion/ rootstock genotype for coffee grafting including 8 treatments of intraspesific grafting of local Robusta/Robusta consisted of Tugu Sari/Bakir, Tugu Hijau/Bakir, Ciari/Bakir, Ersad/Bakir, Tugu Sari/ Garudak, Tugu Hijau/Garudak, Ciari/Garudak, Ersad/Garudak), and 4 treatments of interspecific grafting of Robusta/Liberica (Tugu Sari/Robinson and Tugu Hijau/Robinson) and Arabica/Robusta (Kartika/Bakir and Kartika/Garudak) (Table 1).

15-year-old coffee trees of Bakir, Garudak, and Robinson (local genotypes) having water shoot branches with similar growth were selected as rootstocks. Fourteen grafting were done using method of inlay bark top grafting with one node scion for every replication of treatments. Scion wood was harvested from selected collection trees. Fertilizer of NPK (150-50-100 kg ha-1) was applied. Pruning after harvesting, maintenance pruning $(2 \mathrm{x})$, manual weeding $(1 \mathrm{x})$, and herbicide spraying $(2 \mathrm{x})$ were performed per year. Data collection consisted of percentage of sprouting, vegetative growth of branches, and generative growth including fruiting branch, number of inflorescences, and number of cherries that were being collected at mature stage in 18 months after grafting according to Wintgens and Zamarripa (2004). Data were subjected to analysis of variance and correlation of Pearson.

\section{RESULTS AND DISCUSSION}

Grafting success rate and branch growth were not significantly affected by entrees/under-stump genotype treatments (Table 2). Intraspecific grafting 

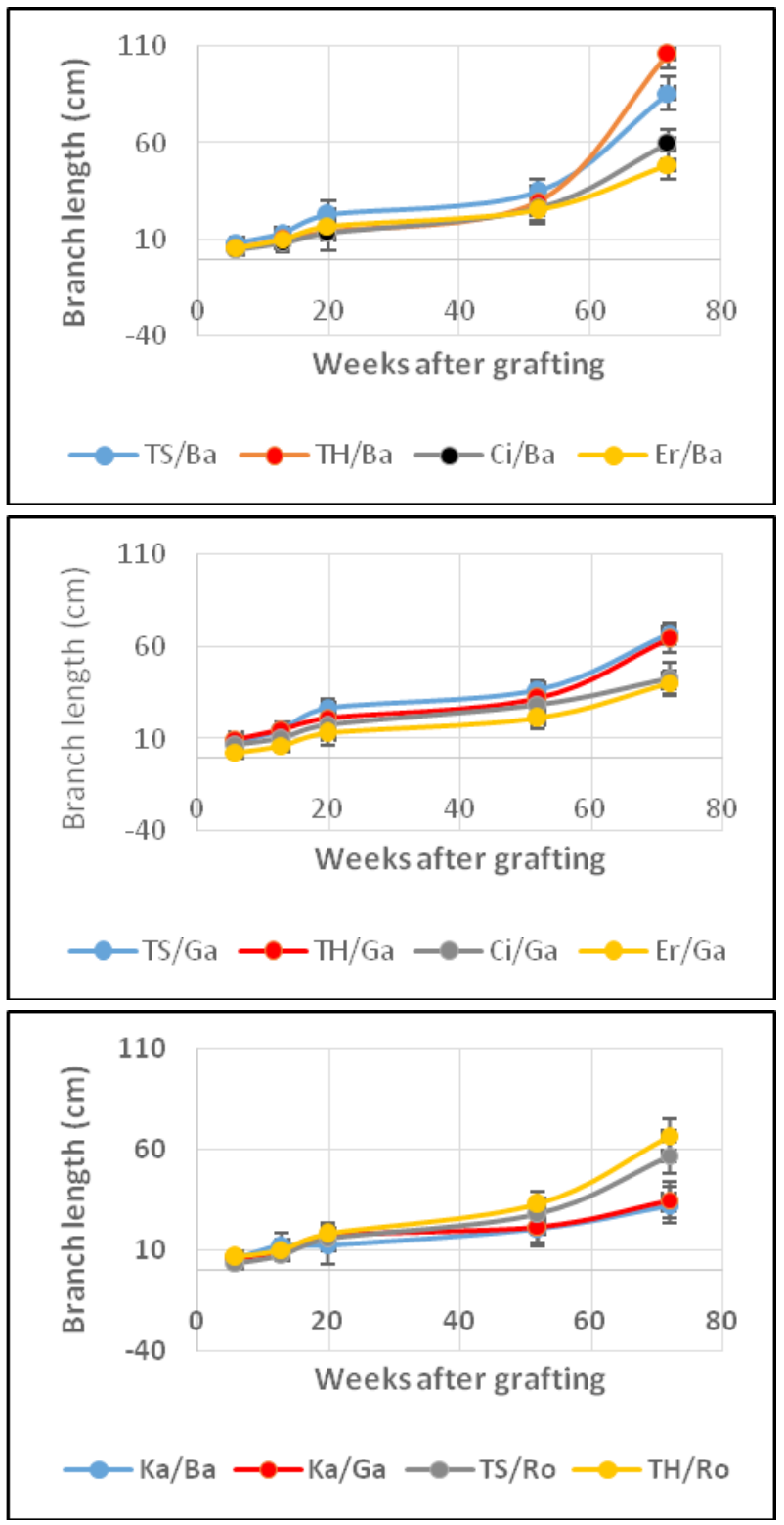

Figure 1. Primary branch length, TS: Tugusari, TH: TuguHijau, Ci: Ciari, Er: Ersad, Ba: Bakir, Ga: Garudak (Robusta), Ro: Robinson (Liberica), Ka: Kartika (Arabica)

of Robusta/Robusta resulted in average grafting sprouting percentage of $90.2 \%$ (mortality rate of $9.8 \%$ ), interspecific grafting of Robusta/Liberica produced $89.1 \%$ sprouting (mortality rate of 10.9\%), and interspecific grafting of Arabica/Robusta resulted in $75.2 \%$ sprouting (mortality rate of 24.8\%). Bertrand and Etienne (2001) reported $13.3 \%$ mortality rate in grafting of Robusta/Robusta, 20\% mortality rate in grafting Arabica/Liberica, and $9.7 \%$ mortality rate in grafting Arabica/
Robusta. For yield improvement of mature trees, farmers in West Lampung District were successful to graft local genotypes of Robusta coffee that were propagated by seed (Bakir and Garudak) with diverse clonal genotypes such as Tugu Sari, Tugu Hijau, Ciari, and Ersad (Evizal, 2013; Evizal et al., 2010). The farmers also commonly inter-planted Liberica coffee (propagated by seed) as rootstock for clonal Robusta genotypes (Evizal et al., 2015).

Under government's program, farmers were still not successful to inter-plant Arabica with Robusta coffee. Arabica cv. Kartika exhibited slower growth than Robusta. Therefore, Arabica coffee cv. Kartika was less compatible to be inter-planted with or to be grafted onto mature Robusta trees as Robusta branches were dominant. When Arabica/Robusta grafting was conducted at seedling stage in a greenhouse as reported by Bertrand and Etienne (2001), the grafting success rate could achieve $87-96 \%$. However, Arabica/Liberica grafting showed less compatibility, as the grafting success rate was only about $79.5 \%$ with slower growth and lower yield. It seems that inter-specific grafting Arabica/Robusta is more suitable for seedling multiplication than for mature coffee cloning as supposed by Alnopri and Hermawan (2015). We suppose that the Robusta under-stump trees need to be full pruned to induce Arabica scion's survival, growth, and development.

Whatever the combination scion/root-stock used for grafting, certain heterogeneity in the plants cannot be avoided due to the interaction between the scion and the root-stock (Wintgens and Zamarripa, 2004). Figure 1 shows primary branch length heterogeneity related to different scion and rootstock genotypes especially for Robusta/ Robusta and Arabica/Robusta grafting. However, Robusta/Liberica grafting showed similar branch length.

Figure 2 shows heterogeneity of number of primary branches related to different scion and 

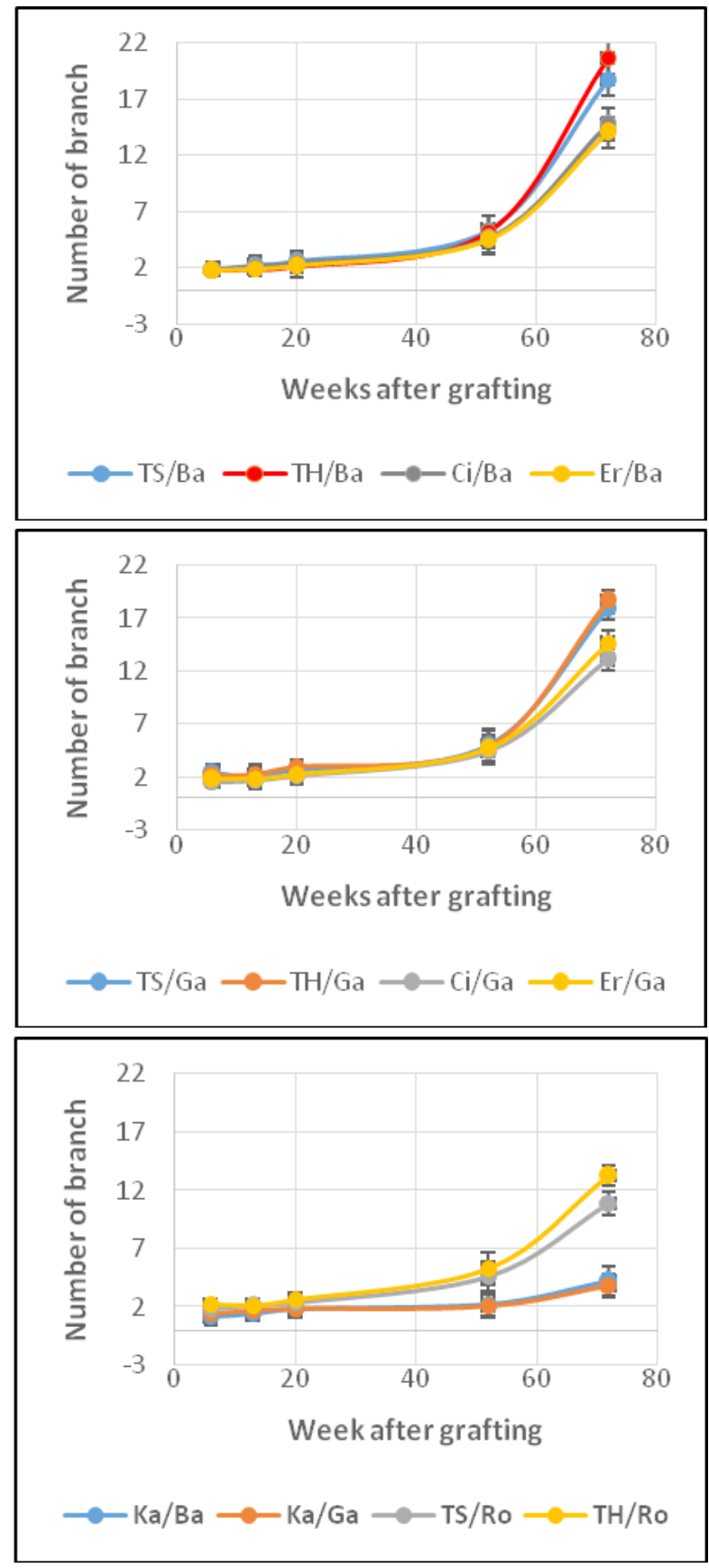

Figure 2. Number of primary branch Remarks: TS: Tugusari, TH: Tugu Hijau, Ci: Ciari, Er: Ersad, Ba: Bakir, Ga: Garudak (Robusta), Ro: Robinson (Liberica), Ka: Kartika (Arabica)

rootstock genotypes. Genotypes of Ciari and Ersad performed slower growth when grafted onto Bakir and Garudak. Genotypes of Tugu Sari and Tugu Hijau showed slower growth when grafted onto Robinson (Liberica). Without total pruning of Robusta rootstock, Kartika/Robusta grafting branches showed significantly slow growth and maturity.
A year after grafting, a branch would achieve its maturity that is showed by flowers growth.

Table 3 shows generative growth of branches a year after grafting. Robusta grafting (Robusta/ Robusta and Robusta/Liberica) had been flowering since the end of the first year after grafting but Arabica/Robusta still had been not flowering. Fruiting branch and cherry inflorescence per branch were affected by entrees and under-stump genotypes. Arabica grafting showed the lowest generative growth. Tugu Hijau/Garudak grafting showed the highest flower inflorescence per branch and Tugu Sari/Garudak grafting showed the highest cherry per inflorescence. Tugu Hijau and Tugu Sari were the main clonal genotypes found in West Lampung District, while Ciari and Ersad were found in North Lampung District (Evizal et al., 2015) especially around Mountain Rigis which were commonly grafted onto Robusta and Liberica under-stump.

Table 4 shows generative growth of branches at the second year after grafting. Fruiting branch and cherry inflorescence per branch were affected by scion and rootstock genotypes. Tugu Hijau/Bakir grafting gave the highest primary branch length and number of fruiting branch. However, variables of cherry inflorescence per branch and cherry inflorescence were not affected by scion and rootstock genotypes. It indicated that different genotypes of scion could result in different branch growth and cherry yield, but it was still inconsistent until the first and the second year of fruiting season. According to Van der Vossen (2001), vigorous coffee trees will have a high rate of new shoot and leaf production to sustain a heavy crop. Lower fruiting branch and cherry inflorescence per branch of Robusta/ Liberica grafting might not indicate an incompatibility as reported by Bertrand and Etienne (2001) for Arabica/Liberica grafting.

Table 5 shows the correlation between variables. Grafting sprouting rate, as variable of grafting 
Table 3. Generative growth in the first year

\begin{tabular}{lcccc}
\hline $\begin{array}{c}\text { Scion/rootstock } \\
\text { genotype }\end{array}$ & $\begin{array}{c}\text { Fruiting branch (Transf. square } \\
\text { root }(\mathbf{x}+0.5)\end{array}$ & $\begin{array}{c}\text { Flower inflorescence } \\
\text { branch }^{-1}\end{array}$ & $\begin{array}{c}\text { Cherry inflorescence } \\
\text { branch }^{-1}\end{array}$ & Cherry inflorescence $^{-1}$ \\
\hline Tugu Sari/Bakir & $2.84 \mathrm{a}$ & $2.46 \mathrm{bc}$ & $2.12 \mathrm{a}$ & $2.51 \mathrm{ab}$ \\
TuguHijau/Bakir & $2.69 \mathrm{a}$ & $2.77 \mathrm{ab}$ & $2.18 \mathrm{a}$ & $2.39 \mathrm{ab}$ \\
Ciari/Bakir & $3.19 \mathrm{a}$ & $2.25 \mathrm{c}$ & $2.18 \mathrm{a}$ & $2.44 \mathrm{ab}$ \\
Ersad/Bakir & $2.81 \mathrm{a}$ & $2.19 \mathrm{c}$ & $2.11 \mathrm{a}$ & $2.31 \mathrm{~b}$ \\
Tugu Sari/Garudak & $3.27 \mathrm{a}$ & $2.18 \mathrm{c}$ & $1.96 \mathrm{a}$ & $2.69 \mathrm{a}$ \\
TuguHijau/Garudak & $3.23 \mathrm{a}$ & $3.13 \mathrm{a}$ & $2.02 \mathrm{a}$ & $2.46 \mathrm{ab}$ \\
Ciari/Garudak & $3.15 \mathrm{a}$ & $2.30 \mathrm{c}$ & $2.09 \mathrm{a}$ & $2.68 \mathrm{a}$ \\
Ersad/Garudak & $2.84 \mathrm{a}$ & $2.19 \mathrm{c}$ & $2.13 \mathrm{a}$ & $2.62 \mathrm{ab}$ \\
Tugu Sari/Robinson & $2.83 \mathrm{a}$ & $2.16 \mathrm{c}$ & $2.07 \mathrm{a}$ & $2.51 \mathrm{ab}$ \\
TuguHijau/Robinson & $2.86 \mathrm{a}$ & $2.14 \mathrm{c}$ & $2.04 \mathrm{a}$ & $2.49 \mathrm{ab}$ \\
Kartika/Bakir & $0.71 \mathrm{~b}$ & $0.71 \mathrm{~d}$ & $0.71 \mathrm{~b}$ & $0.71 \mathrm{c}$ \\
Kartika/Garudak & $0.71 \mathrm{~b}$ & $0.71 \mathrm{~d}$ & $0.71 \mathrm{~b}$ & $0.71 \mathrm{c}$ \\
\hline
\end{tabular}

Note: Numbers followed by the same letter in the same column were not significantly different according to LSD at 5\%.

Table 4. Generative growth of Robusta in the second year

\begin{tabular}{lcccc}
\hline Scion/rootstock genotype & Branch length $(\mathbf{c m})$ & Fruiting branch $^{-1}$ & ${\text { Cherry inflorescence } \text { branch }^{-1}}^{\text {Cherry inflorescence }^{-1}}$ \\
\hline Tugu Sari/Bakir & $85.83 \mathrm{ab}$ & $18.80 \mathrm{ab}$ & $10.40 \mathrm{a}$ & $14.66 \mathrm{a}$ \\
TuguHijau/Bakir & $106.87 \mathrm{a}$ & $20.73 \mathrm{a}$ & $10.26 \mathrm{a}$ & $15.43 \mathrm{a}$ \\
Ciari/Bakir & $59.33 \mathrm{bc}$ & $14.77 \mathrm{abc}$ & $11.56 \mathrm{a}$ & $11.63 \mathrm{a}$ \\
Ersad/Bakir & $48.83 \mathrm{c}$ & $14.07 \mathrm{abc}$ & $8.43 \mathrm{a}$ & $9.90 \mathrm{a}$ \\
Tugu Sari/Garudak & $67.60 \mathrm{bc}$ & $18.67 \mathrm{ab}$ & $11.06 \mathrm{a}$ & $12.63 \mathrm{a}$ \\
TuguHijau/Garudak & $64.27 \mathrm{bc}$ & $18.66 \mathrm{ab}$ & $10.20 \mathrm{a}$ & $15.63 \mathrm{a}$ \\
Ciari/Garudak & $43.23 \mathrm{c}$ & $13.13 \mathrm{bc}$ & $9.53 \mathrm{a}$ & $10.62 \mathrm{a}$ \\
Ersad/Garudak & $46.90 \mathrm{c}$ & $14.70 \mathrm{abc}$ & $8.77 \mathrm{a}$ & $10.36 \mathrm{a}$ \\
Tugu Sari/Robinson & $56.90 \mathrm{bc}$ & $10.90 \mathrm{c}$ & $5.86 \mathrm{a}$ & $11.70 \mathrm{a}$ \\
TuguHijau/Robinson & $66.97 \mathrm{bc}$ & $13.26 \mathrm{bc}$ & $5.63 \mathrm{a}$ & $10.10 \mathrm{a}$ \\
\hline
\end{tabular}

Note: Numbers followed by the same letter in the same column were not significantly different according to LSD at 5\%.

success rate, was less correlated with variables of growth. Branch girth was correlated with leaf expansion (length and width of leaf). Leaf expansion and length of branch were commonly correlated with other growth variables as also reported by Covre et al. (2016). Number of inflorescences, as variable of generative growth, was not correlated with vegetative growth. Wintgens (2004) stated that the flowering of coffee was controlled by hormones influenced by branch growth and water stress during dry season. The more severe the dry season the more intense the flowering. Thereafter the dormant flowers are broken by sudden rainfall before starting to blossom.

\section{CONCLUSION}

Intraspecific grafting of Robusta/Robusta, Robusta/Liberica, and Arabica/Robusta resulted in grafting mortality rate of $9.8 \%, 10.9 \%$, and $24.8 \%$, respectively. Until 28 weeks after grafting, branch growth variables were significantly affected by scion/rootstock genotype treatments including Robusta/Robusta, Robusta/Liberica, and Arabica/ Robusta grafting. Arabica/Robusta coffee graft- 
Table 5. Correlation coefficient between variables

\begin{tabular}{|c|c|c|c|c|c|c|c|c|c|c|}
\hline Variable & SG & BG & $\mathrm{NL}$ & LL & $B L$ & LPB & LSB & NPB & NSB & $\mathrm{NI}$ \\
\hline SG & 1 & 0,43 & 0,36 & 0,50 & 0,49 & $0,61 *$ & 0,42 & 0,16 & 0,33 & 0,41 \\
\hline BG & & 1 & 0,29 & $0,64^{*}$ & $0,63^{*}$ & 0,42 & 0,48 & 0,39 & 0,18 & 0,27 \\
\hline NL & & & 1 & $0,60^{*}$ & $0,65^{*}$ & $0,78^{* *}$ & $0,65^{*}$ & $0,69 * *$ & $0,84^{* *}$ & 0,32 \\
\hline LL & & & & 1 & $0,96^{* *}$ & $0,81^{* *}$ & $0,76^{* *}$ & $0,57^{*}$ & $0,75^{* *}$ & 0,22 \\
\hline$B L$ & & & & & 1 & $0,82^{* *}$ & $0,80 * *$ & 0,48 & $0,73^{* *}$ & 0,32 \\
\hline LPB & & & & & & 1 & $0,68 * *$ & $0,61 *$ & $0,82^{* *}$ & 0,32 \\
\hline LSB & & & & & & & 1 & $0,63^{*}$ & $0,59^{*}$ & 0,44 \\
\hline NPB & & & & & & & & 1 & $0,69 * *$ & 0,06 \\
\hline NSB & & & & & & & & & 1 & 0,22 \\
\hline $\mathrm{NI}$ & & & & & & & & & & 1 \\
\hline
\end{tabular}

Note: $\quad S G=$ sprouting grafting, $B G=$ branch girth, $N L=$ number of leaf; $L L=$ length of leaf; $B L=$ broad of leaf; $L P B=$ length of primary branch, $L S B=$ length of secondary branch, NPB = number of primary branch; NSB = number of secondary branch; $N I=$ number of inflorescence (Correlations Pearson, at * 0.05 and ${ }^{* *} 0.01$ significance).

ing showed the poor growth performance. In the second year of Robusta/Robusta and Robusta/ Liberica growth, generative growth of cherry inflorescence per branch and number of cherries per inflorescence were not affected by scion and rootstock genotypes. Leaf and branch growth were very important variables correlated with other variables.

\section{ACKNOWLEDGEMENT}

The authors would like to thank the LPPM of University of Lampung for funding through Research Grant in year 2017.

\section{REFERENCES}

Alnopri and B. Hermawan. (2015). Sustainability for Growth and Productivity of Arabica Coffee in Lowland Regions of Bengkulu Province. International Journal on Advanced Science Engineering Information Technology 5 (5): 304-307

Bertrand, B. and H. Etienne. (2001). Growth, Production, and Bean Quality of Coffea Arabica as Affected by Interspesific Grafting: Consequences for Rootstock Breeding. Hort Science 36(2): 269-273

Covre, A.M., L. Canal, F.L. Partelli, R.S. Alexandre, A. Ferreira, and H.D.Vieira. (2016). Development of Clonal Seedlings of Promising Conilon coffee (Coffea canephora) genotypes. Australian Journal of Crop Science 10 (3): 385-392

Evizal, R., Tohari, I.D. Prijambada, J. Widada, F.E. Prasmatiwi, and Afandi. (2010). The Influence of Shade Coffee Agro-Ecosystem on Productivity and Farming Sustainability. Jurnal Agrotropika. $15(1): 17-22$

Evizal, R. (2013). Ethno-agronomy of Coffee Plantation Management in Sumberjaya West Lampung District. Jurnal Agrotrop $3(2): 1-12$
Evizal, R., Sugiatno, and F.E. Prasmatiwi. (2015). Variability of coffee cultivars in Lampung. Agrotrop 5(1): 80-88

Fahl, J.I., M.C.L. Carelli, H.C. Menezes, P.B. Gallo, and P.C.O. Trivelin. (2001). Gas exchange, Growth, Yield and Beverage Quality of Coffea arabica Cultivars Grafted on to C. canephora and C. congensis Experimental Agriculture 37: 241-252

Junior, S.A., R.S. Alexandre, E.R. Schmildt, F.L. Partelli, M.A.G. Ferrao, and A.L. Mauri. (2013). Comparison Between Grafting and Cutting as Vegetative Propagation Methods for Conilon Coffee Plants. Maringa 35 (4): 461-469

Novaes, P., J.P. Souza, and C.H.B.S. Prado. (2011). Grafting for Improving Net Photosynthesis of Coffea Arabica in Field in Southeast of Brazil. Experimental Agriculture 47(1): 53-68

Pranowo, D. and H. Supriadi. (2013). Evaluation of Grafted Plants from Nine of Robusta coffee Clones with Local Rootstock. Buletin Ristri 4 (3): 231-236

Tomaz, M.A., N.S. Sakiyama, H.E.P. Martinez, A.A. Pereira, L. Zambolim, and C.D. Cruz. (2002). Grafted Young Coffee Tree Growth in A Greenhouse. Crop Breeding and Applied Biotechnology 2(3): 425-430

Udarno, M.L. and R.T. Setiyono. (2015). Excels a Coffee Performance of Meranti Islands District, Riau. Pros. Sem. Nas. Masy. Biodiv. Indon. 1(3): 543-547

Van der Vossen, H.A.M. (2001). Agronomy I: Coffee Breeding Practices. In: Clarke, R.J. and Vitzthum, O.G. (Eds.). Coffee Ricent Developments. Blackwell Science. Oxford. 184-201p

Warshefsky, E.J., L.L. Klein, M.H. Frank, D.H. Chitwood, J.P. Londo, E.J. von Wettberg, and A.J. Miller. 2016. Rootstocks: Diversity, Domestication, and Impact on Shoot Phenotypes. Trends Plant Sci. 21(5): 418-437

Wintgens, J.N. 2004. The Coffee Plant. In: Wintgents, J.N. (Ed). Coffee: Growing, Processing, Sustainable Production. Wilei-VCH. Weinheim. 3-24p

Wintgens, J.N. and A. Zamarripa. 2004. Coffee Propagation. In: Wintgents, J.N. (Ed). Coffee: Growing, Processing, Sustainable Production. Wilei-VCH. Weinheim. 87-136p 